\title{
Upaya Pencegahan Covid-19 dengan Disiplin Menerapkan Protokol Kesehatan di Desa Banyudono, Kecamatan Banyudono, Kabupaten Boyolali
}

\author{
Raka Angger Pamungkas ${ }^{\mathrm{a}, 1}$, Tegar Harbriyana Putra ${ }^{\mathrm{b}, 2, *}$ \\ ${ }^{a}$ Fakultas Ilmu Komputer Universitas Boyolali, Jl. Pandanaran 405 Boyolali, Boyolali 57315, Indonesia \\ ${ }^{\mathrm{b}}$ Fakultas Hukum Universitas Boyolali, J1. Pandanaran 405 Boyolali, Boyolali 57315, Indonesia \\ ${ }^{1}$ rakape85@gmail.com; ${ }^{2}$ tegarharbriyanaputra@gmail.com \\ * Koresponsendi penulis
}

ARTICLE INFO

Article history

Menerima 19 April 2021

Revisi 4 Juli 2021

Diterima 21 Juli 2021

Kata Kunci

Covid-19

Virus

Health protocols

\section{ABSTRACT}

In 2021 Indonesia is still not free from the covid-19 virus, Banyudono Village, Banyudono Village, Banyudono District, Boyolali Regency is one of the densely populated villages in the Banyudono District which is still a green zone from the covid-19 virus, therefore people must remain maintain health to avoid disease, the problem that arises is the lack of awareness of the importance of implementing health protocols correctly according to government recommendations to avoid the covid-19 virus. The majority of the population who work outside the environment cannot carry out WFH, there are many out there who have contracted the covid-19 virus, this is the focus so that villagers stay away from the virus. Community service focuses on disseminating the procedures for implementing health protocols correctly and providing knowledge of how dangerous the COVID-19 virus is. After the activity was carried out, villagers began to awaken themselves to comply with health protocols and begin to understand the dangers of the virus starting from wearing masks when doing activities outside the home and keeping a distance from each other.

This is an open access article under the CC-BY-SA 4.0 license.

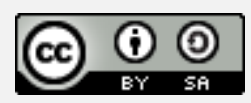

\section{Pendahuluan}

Pada tahun 2021 Indonesia masih belum bisa terbebas dari pandemi virus Covid-19, Terdeteksi virus ini muncul pertama kali di Wuhan, China pada Desember 2019[1]. Penyebaran virus ini terjadi sangat cepat hanya dalam gitungan beberapa bulan saja, virus ini sudah bisa masuk ke beberapa negara termasuk Indonesia. Virus corona ini menginfeksi dan menyerang saluran pernapasan dan menyebabkan demam tinggi, batuk, pilek, flu, sesak nafas serta nyeri tenggorokan. Seiring berjalannya waktu, tidak lama ini telah ditemukan riset bahwa virus corona tidak hanya menginfeksi dan menyerang saluran pernapasan saja, melainkan sudah berkembang menyerang system pencernaan dengan adanya gejala diare, mati rasa pada indra perasa atau lidah, mual dan muntah yang disertai dengan demam tinggi. Penyebaran virus ini sangat cepat hingga memakan banyak korban nyawa di berbagai Negara. Awalnya di Indonesia hanya 2 orang yang positif, namun dalam waktu beberapa hari, setiap hari ada penambahan korban dan orang yang terpapar serta dinyatakan positif corona. Sehingga pemerintah mengambil keputusan untuk menyiapkan rumah sakit daerah sebagai rumah sakit rujukan untuk masyarakat yang terjangkit Covid-19.

Kegiatan mural sebagai media pendidikan dan pengabdian masyarakat yang menjadi bahan kajian. Kajian diarahkan terkait efektivitas mural sebagai media pendidikan dan pengabdian masyarakat[2].

Penerapan dan pemanfaatan Teknologi Informasi dan Komputer (TIK) dalam proses pembelajaran memiliki beberapa tujuan diantaranya adalah dapat dikembangkan strategi, metode pembelajaran yang lebih menarik, efektif dan efisien. Bertujuan melahirkan generasi muda yang menguasai TIK, kreatif dan inovatif serta berupaya membawa ekonomi kepada era informasi, perluasan sumber- sumber belajar terutama dalam bentuk digital dari internet, perluasan jaringan kerjasama (networking) dan kemitraan dengan lembaga maupun sekolah lain dalam mendukung pengembangan sekolah [3]. 
Pengabdi dapat memberikan bantuan pengerjaan soal-soal yang sulit untuk dikerjakan oleh siswa dikarenakan keterbatasan pemahaman materinya, siswa merasa terbantu dengan tambahan materi yang diberikan selama kegiatan KKN Tematik Covid-19 ini, siswa juga merasakan pendidikan yang mereka jalani tidak merasa terhambat walaupun ada pandemi Covid-19, dan proses transfer ilmu dapat dilakukan[4].

Meningkatkan kualitas wawasan dan kesadaran pelaku usaha tentang pentingnya tampilan kemasan suatu produk untuk bersaing di era milenial pasar bebas. kegiatan pengabdian dengan tujuan untuk melihat dan menganalisis kebutuhan pasar agar strategi pemasaran yang akan dirancang sesuai dengan kondisi yang sebenarnya[5].

Mendukung dan mendorong jiwa enterpreneurship yang menjadikan kemandirian personal. Program Pengabdian dilakukan dengan tema budidaya tanaman secara hidroponik untuk mendukung kemandirian masyarakat pesantren. Program ini dimaksudkan agar para santriwati dapat belajar secara langsung sistem budidaya Hidroponik sebagai bekal pengembangan diri bagi para santri sudah lulus. Program pengabdian terdiri dari 2 sesi yang pertama pemaparan dan diskusi dengan materi hidroponik, sesi kedua terdiri dari pemasangan instalasi hidroponik, pelatihan persemaian, penanaman bibit pada hidroponik sistem wick system dan nutrient film system[6].

Menyampaikan informasi mengenai teknologi budidaya tanaman obat melalui ceramah, diskusi, dan demonstrasi praktik langsung budidaya tanaman obat di lahan pekarangan. Evaluasi peningkatan pengetahuan peserta dilakukan dengan pre- dan post-test setelah dilakukan penyuluhan dan praktik budidaya. Evaluasi ketrampilan peserta dilakukan pada saat demonstrasi praktik langsung budidaya tanaman obat di lahan pekarangan dilakukan[7].

Dengan adanya sistem informasi ini diharapkan dapat membantu pengelola progdi, fakultas, dan LPPM untuk memperoleh data yang lebih akurat. Selain itu dengan adanya sistem informasi ini pihak UP2M (Unit Penelitian dan Pengabdian Kepada Masyarakat) FTIK dapat melakukan monitoring terhadap pelaksanaan kegiatan penelitian dan pengabdian kepada masyarakat dengan dana internal dari LPPM USM[8].

Menghasilkan dokumentasi dari rancangan sistem informasi dan program aplikasi untuk mendukung kegiatan penelitian dan pengabdian kepada masyarakat dalam hal pengelolaan data di Universitas $\mathrm{MH}$ Thamrin[9].

Meningkatkan pengetahuan kader tentang PTM dan Posbindu PTM. Selain kegiatan pelatihan, FK UNPATTI juga menyerahkan paket peralatan Posbindu PTM Dasar bagi setiap Puskesmas di Pulau Saparua dan beberapa dokumen Posbindu untuk digunakan kader sebagai panduan dan alat edukasi. Kegiatan pengabdian kepada masyarakat ini diharapkan dapat menjadi salah satu faktor pendorong pelaksanaan kegiatan Posbindu PTM di Pulau Saparua di waktu mendatang[10].

Membuat sistem informasi manajemen yang terkomputerisasi dimana dosen yang akan melakukan pengajuan proposal dan laporan tidak perlu mencetak atau print proposal dan laporan[11].

Hasil peneltian tersebut dapat diberikan pemahaman kepada masyarakat untuk dapat memanfaatkan daun sukun sebagai salah satu minuman kesehatan, baik digunakan sebagai kreativitas di rumah tangga maupun untuk dapat dipasarkan (dijual)[12].

Pembuatan sistem LPPM ini adalah untuk mengelola dan mengorganisir data-data penelitian dan pengabdian masyarakat yang akan dan telah dilakukan oleh dosen di lingkungan Akademik BSI agar dapat menampung dan mempercepat kinerja layanan LPPM Akademik BSI dalam kegiatan yang berhubungan dengan penelitian, pengabdian masyarakat dan berita-berita (informasi dari luar)[13].

Perubahan terencana harus memiliki tujuan yang ganda sifatnya, yaitu meliputi perubahan dalam lingkungan fisik dan perubahan dalam lingkungan sosial. Perubahan lingkungan fisik biasanya diwujudkan dalam bentuk-bentuk pengadakan bangunan, alat-alat teknis, dan hal-hal lain yang bersifat fisik dan dapat dilihat oleh indera mata. Sementara perubahan dalam lingkungan sosial adalah perubahan menyangkut perubahan yang terjadi dalam perilaku manusianya. Perubahan dalam lingkungan sosial harus sampai pada perubahan etos[14].

Maraknya pandemic Covid-19 ini, dan semakin cepatnya peningkatan jumlah korban yang terpapar positif Covid-19 membuat beberapa Negara termasuk Indonesia juga menerapkan kebijakan untuk memberlakukan lockdown dalam rangka mencegah penyebaran virus Corona. Di Indonesia juga diberlakukan kebijakan Pembatasan sosialisasi Berskala Besar (PSBB) untuk menekan penyebaran virus ini. Virus ini menular melalui percikan dahak (droplet) dari saluran pernapasan. Pencegahan penularan virus corona tidak hanya bisa dilakukan dengan cara lockdown atau PSBB saja, tak kala penting setiap individu juga dapat 
menerapkan protokol kesehatan untuk bisa memproteksi dirinya sendiri dari paparan virus corona. Oleh karena itu penting untuk melakukan sosialisasi kepada masyarakat tentang tentang penerapan protokol kesehatan 3M untuk mencegah penularan dan menekan penyebaran Covid-19. 3M adalah salah satu jargon dimasa pandemic ini untuk mencegah dan menekan penyebaran Covid-19. 3M ini adalah mencuci tangan, memakai masker dan menjaga jarak.

Kegiatan ini dilaksanakan di Desa Banyudono RT 4 RW 1 yang merupakan salah satu RT yang padat penduduk di Desa Banyudono. Dari hasil observasi dan dialog dengan Ketua RT setempat, warga yang bertempat tinggal di RT 4 RW 1 masih bekerja dan di tempat bekerja tidak dilaksanakan kegiatan Work From Home atau yang sering disebut dengan WFH, hal ini merupakan salah satu sorotan yang penting karena beraktifitas diluar rumah khususnya ditempat kerja dapat merupakan salah satu tempat penularan virus jika tidak menerapkan protokol kesehatan dengan benar, terdapat beberapa permasalahan yang ada dilokasi antara lain kurangnya edukasi tentang bahaya virus covid-19, sosialisasi penerapan protocol kesehatan yang benar sesuai anjuran pemerintah. Adapun permasalahan permasalahan yang diidentiifikasi, antara lain :

Kurangnya kesadaran untuk mematuhi protokol kesehatan, maka dilakukan kegiatan edukasi tentang pencegahan covid-19 dan melakukan penerapan protokol kesehatan sesuai anjuran pemerintah.

\section{Metode}

Kegiatan ini merupakan pragmatis yang dilakukan dengan metode Parsipatory Learning and Action (PLA). PLA merupakan sebuah pendekatan pemberdayaan yang memiliki keunggulan baik secara filosofis maupun nilai aksi dengan mengutamakan pada proses belajar bersama[15].

a. Mengajak pemuda karang taruna Desa Banyudono untuk bergabung mengikuti kegiatan upaya pencegahan covid-19 dengan menerapkan protokol kesehatan.

b. Mengajarkan anggota karang taruna yang ingin mempelajari desain grafis, kegiatan ini bertujuan untuk membuat stiker dan poster $3 \mathrm{M}$ dan tata cara penerapan protokol kesehatan dengan benar untuk digunakan dalam sosialisasi terhadap masyarakat untuk menerapkan protokol kesehatan dengan benar agar terhindar dari tertularnya virus covid-19.

c. Mengadakan sosialisasi terhadap penjual, pembeli dipasar dan masyarakat Desa Banyudono untuk menerapkan protokol kesehatan dengan benar, dan dibarengi dengan pembagian masker dan stiker $3 \mathrm{M}$ hasil desain dari pemuda karang taruna.

\section{Hasil dan Pembahasan}

\subsection{Hasil}

Kegiatan Kuliah Kerja Nyata yang dilaksanakan oleh mahasiswa Universitas Boyolali di Desa Banyudono dilaksanakan dengan menjalankan beberapa program kerja yang diuraikan sebagai berikut :

a. Pembuatan Stiker 3M

Pembuatan Stiker 3M melibatkan pemuda karang taruna di Desa Banyudono, Mengajarkan tata cara mendasain sebuah gambar dengan mengunakan aplikasi Corel Draw dan menjelaskan fungsi dan kegunaan tool yang tersedia didalam aplikasi untuk mendasain. Kegiatan ini bertujuan untuk mengajarkan kepada pemuda karang taruna untuk mengekpresikan kreatifitasnya dalam. Hasil dari desain stiker 3M digunakan untuk gambaran sosialisasi nanti terhadap masyarakat.

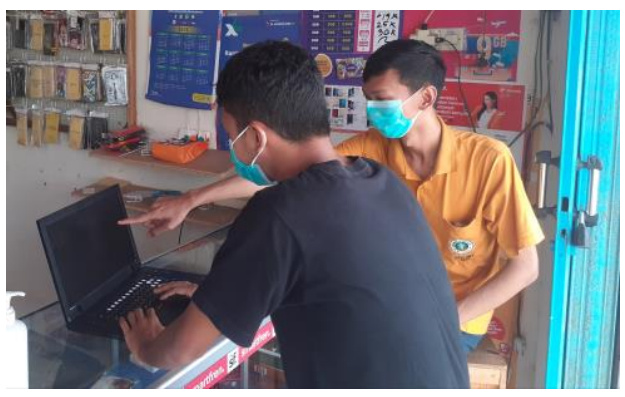

Fig. 1 Mengajarkan cara mendesain 
b. Melakukan Sosialisasi Pentingnya Penerapan Protokol Kesehatan di Lingkungan Pasar dan Masyarakat

Upaya ini dilakukan untuk mengedukasi masyarakat tata cara penerapan protokol kesehatan dengan benar sesuai anjuran pemerintah. Dengan membagikan masker dan stiker $3 \mathrm{~m}$ yang telah dibuat kepada penjual dan pembeli di area Pasar Ngancar Banyudono, dan warga masyarakat Desa Banyudono. Kegiatan ini dibarengi dengan kegiatan bagi bagi masker.

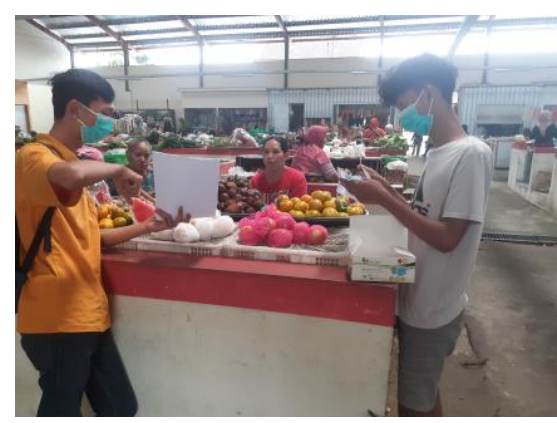

Fig. 2 Sosialisasi penerapan protokol kesehatan di lingkungan pasar

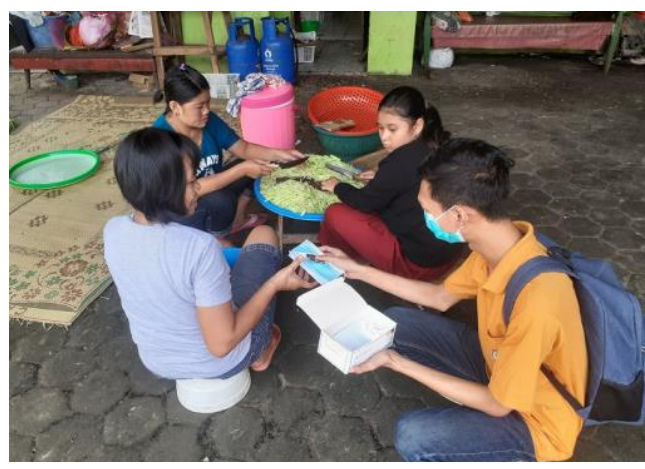

Fig. 3 Pembagian masker terhadap masyarakat

\subsection{Pembahasan} bahwa:

Kegiatan pengabdian di Desa Banyudono berjalan lancar, dari hasil pembahasan dapat disimpulkan

a. Kegiatan pelatihan mendasain stiker $3 \mathrm{M}$ dengan menggunakan laptop yang mengajarkan tata cara mendasain, aplikasi yang digunakan serta menjalankan fungsi fungsi keguanaan aplikasi berjalan sangat efektif dalam meningkatkan pengetahuan dan kemampuan. Kegiatan ini dilakukan oleh anggota karang taruna di Desa Banyudono.

b. Sosialisasi yang dilaksanakan di Pasar Ngancar Banyudono mempunyai tujuan yang diharapkan, yaitu meningkatnya pengetahuan kepada masyarakat tentang bahaya virus covid-19 dan warga lebih sadar akan disiplin menerapkan protokol kesehatan dengan benar sesuai anjuran pemerintah. Karena dengan kesadaran diri untuk menerapkan protokol kesehatan dapat memutus rantai penyebaran virus covid-19.

Dari kegiatan kegiatan yang telah terlaksana diatas dapat disimpulkan bahwa program pengabdian yang dilaksanakan secara garis besar berbagai program yang telah direncanakan, terlaksana dengan baik terhadap program yang telah dilaksanakan. Dari sisi yang lain, sambutan dan partisipasi dari masyarakat sangat baik terhadap program program yang telah dilaksanakan.

\section{Kesimpulan}

4.1 Kesimpulan

Beberapa hal yang bisa disimpulkan dari kegiatan pengabdian masyarakat ini adalah :

Pada umumnya permasalahan yang terjadi di masyarakat Desa Banyudono adalah kurang kesadarannya akan pentingnya menerapkan protokol kesehatan dengan benar sesuai anjuran pemerintah, terutama warga 
yang sering berakifitas diluar rumah dan yang masih bekerja bertemu orang banyak dan tidak dapat melaksanakan wfh, hal ini yang merupakan salah satu jalur penularan virus.

Kegiatan pengabdian kepada masyarakat ini telah dapat memberikan pengetahuan kepada masyarat betapa pentingnya menerapkan protokol kesehatan dengan benar, dan masyarakat mulai tersadar dirinya betapa bahaya virus covid-19 dan mulai patuh menerapkan protokol kesehatan. Dan anggota karang taruna yang mengikuti kegiatan belajar mendesain dapat memanfaatkan waktu luangnya untuk membuat karya yang dapat dikreatifitaskan sendiri untuk kegiatan lain kedepannya.

\subsection{Saran}

a. Perlu adanya kegiatan monitoring dan pengawasan dari pemerintah Desa, khususnya satgas desa agar kegiatan ini depat berjalan dengan baik dan dilaksanakan secara terus menerus agar masyarakat desa terhindar dari virus covid-19

b. Ketrampilan yang diberikan kepada pemuda karang taruna berupa mendesain gambar dapat dikembangkan lagi dan bisa menjadi pemasukan anggota karang taruna jika mempunyai modal untuk membuka percetakan ataupun jasa desain.

\section{Daftar Pustaka}

[1] M. H. Sukur, "Penanganan Pelayanan Kesehatan Di Masa Pandemi Covid-19 Dalam Perspektif Hukum Kesehatan,” J. Inicio Legis Vol. 1 Nomor 1 Oktober 2020, vol. 1, pp. 1-17, 2020.

[2] D. Endriawan, T. A. Maulana, and ..., "Mural sebagai Media Pendidikan dan Pengabdian Masyarakat," Semin. Nas. Seni dan ..., pp. 482-485, 2017, [Online]. Available: https://media.neliti.com/media/publications/196120-mural-sebagai-media-pendidikan-dan-pengac50e43d6.pdf.

[3] M. Mayeni, "Sosialisasi Teknologi Informasi: Pengabdian Masyarakat pada Siswa SMK Taruna Bhakti Depok," JATI EMAS (Jurnal Apl. Tek. dan Pengabdi. Masyarakat), vol. 1, no. 1, p. 21, 2017, doi: 10.36339/je.v1i1.15.

[4] D. Sulistyaningrum and R. R. Al Hakim, "Pendampingan Pembelajaran Siswa Melalui Teknologi Informasi Selama Pandemi Covid-19: Studi Kasus KKN Tematik Covid-19," ANDASIH J. Pengabdi. Kpd. Masy., vol. 1, no. 2, pp. 1-7, 2020.

[5] D. L. Fay, "PENGABDIAN MASYARAKAT PENERAPAN TEKNOLOGI TEPAT GUNA ALAT JAHIT KARUNG BERAS SETRA RAMOS," Angew. Chemie Int. Ed. 6(11), 951-952., vol. 4, pp. 72-76, 2021.

[6] S. Madusari, D. Astutik, A. Sutopo, and A. S. Handini, "INISIASI TEKNOLOGI HIDROPONIK GUNA MEWUJUDKAN KETAHANAN PANGAN MASYARAKAT PESANTREN," J. Pengabdi. Masy. Tek., vol. 2, no. 2, pp. 45-52, 2020, doi: 10.24853/jpmt.2.2.45-52.

[7] S. P. Dewi and I. Widiyawati, "Pengenalan Teknologi Budidaya Tanaman Obat sebagai Upaya Pemanfaatan Lahan Pekarangan di Kelurahan Pabuwaran Purwokerto, Jawa Tengah," J. Panrita Abdi, vol. 3, no. 2, pp. 107-111, 2019.

[8] S. Handayani, "Rancang Bangun Sistem Informasi Penelitian dan Pengabdian Dosen Fakultas Teknologi Informasi dan Komunikasi (FTIK) Universitas Semarang (USM)," Infokam, vol. 13, no. 1, pp. 11-22, 2017, [Online]. Available: http://amikjtc.com/jurnal/index.php/jurnal/article/view/116.

[9] R. Agustino, "Sistem Informasi Penelitian dan Pengabdian Masyarakat," J. Jaring Saintek, vol. 2, no. 1 , pp. 1-12, 2020, [Online]. Available: http://ejurnal.ubharajaya.ac.id/index.php/jaringsaintek/article/view/61.

[10] D. L. Fay, "KEGIATAN PENGABDIAN MASYARAKAT DI PULAU SAPARUA, MALUKU: PERSEPSI DAN PENGETAHUAN KADER TENTANG POS PEMBINAAN TERPADU PENYAKIT TIDAK MENULAR,” Angew. Chemie Int. Ed. 6(11), 951-952., vol. 14, pp. 75-86, 2021.

[11] \& M. Melyanti, R., Iqbal, M., "Sistem Informasi Manajemen Penelitian Dan Pengabdian Masyarakat Di Bagian P3M (Studi Kasus: Stmik Hang Tuah Pekanbaru)," J. Ilmu Komput., vol. 9, no. 2, pp. 165-176, 2020, [Online]. Available: http://jik.htp.ac.id. 
[12] T. gilang pradana Risdawati Br. ginting, Mudhita ikkrullah ritonga, andhika putra, "Pengabdian Masyarakat Pemanfaatan Daun Sukun (Artocarpus altilis) sebagai Minuman Kesehatan di Kelurahan Tanjung Selamat- Kotamadya Medan,” Anim. Sci. Agron., vol. 4, pp. 18-28, 2019.

[13] G. B. Putra, "Rancang Bangun Sistem Penelitian Dan Pengabdian Masyarakat Universitas Bangka Belitung Berbasis Web Server," J. ECOTIPE, vol. 4, no. 1, pp. 17-22, 2017, doi: 10.33019/ecotipe.v4i1.14.

[14] M. Soehadha, "Integrasi Islam dan Sains Teknologi dalam Pengabdian Masyarakat; Transformasi Islam dalam Wilayah Praksis Keseharian Masyarakat," Apl. J. Apl. Ilmu-ilmu Agama, vol. 19, pp. 153-162, 2020, [Online]. Available: http://ejournal.uinsuka.ac.id/pusat/aplikasia/article/download/2229/1692.

[15] A. F. Silmi, "PARTICIPATORY LEARNING AND ACTION (PLA) DI DESA TERPENCIL: Peran LSM PROVISI Yogyakarta dalam Pemberdayaan Masyarakat di Lubuk Bintialo, Sumatra Selatan," J. Pemberdaya. Masy. Media Pemikir. dan Dakwah Pembang., vol. 1, no. 1, p. 97, 2017, doi: 10.14421/jpm.2017.011-05. 